\title{
10 “I Like Everything but Air-Condition": How Refugee Children React to the American Way of Life
}

Peter is eleven now and a terrible problem in class. He walks out of the room, or even leaves school, whenever he feels like it; he doesn't do any homework. From time to time he beats up other children in school and fights with his teacher. He certainly was no «model child» when he came over to this country from France three years ago, but these difficulties started only a year ago, after an incident in his former school. It was an incident rather rare enough in our New York City schools and yet highly illustrative and instructive in relation to many behaviour problems of refugee or immigrant children.

Peter's class was preparing for the next school assembly in which one of the members of the class was to carry the flag from the rear of the assembly room to the front and another was to lead the group in recitation of the allegiance to the flag. Peter wanted to have one of the two parts in the ceremony, but the teacher, who liked Peter but forgot herself for the moment, said to him: "Oh no, Peter, you still have an accent."

Peter flew into a terrible temper tantrum. He threw his books at the teacher, spit into her face and ran away from class. The next day Peter fought with the teacher and the pupils, starting with the one carrying the flag, and ever since then he has been a problem in school and at home. Principal and teacher have tried to help him. Peter changed classes and even schools, but so far in vain.

Peter's case is illustrative and instructive, to be sure, but certainly not at all characteristic of refugee and immigrant children in this country and of the role the school plays in their adjustment. It is now more than a year since the author of this article made a study, with the New York School of Social work, in which 214 refugee children who had come to this country from 16 different countries were interviewed, wrote papers and answered questionnaires in regard to their former experiences, their adjustment, their problems and their opinions on the differences between then and now.

"How do you get along in school? How do you like your present school? How was school in in your native country?" Such were some of our questions on the school problem.

"U.S. schools are not so strictly ruled and on the whole I like them better. I get along very well but not very good," writes an English boy of thirteen, and 
another English boy, eleven years old, expresses tersely what he finds most important: "No caning here. It is nice." "U.S. schools are easier," writes an English girl of ten, "There are boys in my class; no boarding schools."

"Schools (in Italy)," says an Italian girl now 20 years old, "was nice and the method of teaching quite good. I liked it, but, I don't miss it because I am conscious now of the way that most moral values were being distorted to suit the purpose of a Fascist education. I attended school in Argentina but did not like it. U.S. schools treat all subjects in a much more specialized way; they are therefore superior in all scientific subjects but inferior in all literary courses."

A girl of sixteen from Germany writes: "In U.S. more emphasis is placed on things which I believe are really useful; although my present school

(Hunter College High School) is academical, we are not weighed down by too much dead knowledge. Besides we have more freedom in choosing our subjects, which - if limited - I think definitely worth copying."

"If one girl would have dared to have lipstick on, she would have been expelled from school," says a girl, who had attended schools in Germany and France, summing up an apparently important difference from our schools here.

"Languages and mathematics were taught at earlier stages. Rules and regulations pertaining to our behaviour were more strict, and there were more of them. I liked it, especially since I did not know anything else. I think we learned more than in any given year, although we did not have as many subjects to choose from. The main difference exists in the student-teacher relations. Respect and strict subjugation must be observed by students of all ages. However there were exceptions and many teachers became to be quite human- especially the younger ones. U.S. schools seems to allow a greater development of the students initiative, because he may choose most of his subjects. After my Junior year in high school and throughout college my being an alien did not bother me in my relations with my fellow students anymore. I made good in in high school and hence was able to go to college. When they did find out that was a refugee they honoured me all the more." The German boy who wrote thus, is now fighting overseas with the U.S. Army.

The Commissioner of Education of the State of New York sent out questionnaires to students who previously attended secondary schools in foreign countries. These excellently worded questionnaires addressed the students through their principals in the following words: "Probably at no other time will American schools have opportunity to profit more by advice and suggestions 
of students who have attended schools in other countries. We are asking your help in regard to several aspects of high school life." Some frequent suggestions for improvement in our high schools were: More outdoor sports in the school program; a more varied program; less homework. Refugee children were very much impressed by the attention their experience was receiving. The questionnaires helped many of them to an easier adjustment in school. They had feared that ther being students from foreign countries would be regarded as something of which they must be ashamed. Now their principals were telling them that the American school would "profit by the advice and suggestions of students who have attended schools in other countries."

Without doubt Peter's experience in his school was unusual and not at all characteristics of any school in this country, but the fact that he is so touchy and easily disturbed when not treated as an equal in school or anywhere else is highly characteristic of almost all the refugee and immigrant children. It is characteristic even of children who have moved into a new section from another part of the country. But with refugee children this need for acceptance as an equal is of even greater importance because one of the chief emotional difficulties in their young lives has been the fact of racial, national or political persecution, the fact of not being accepted by the surrounding community.

It is no wonder that almost all the children who answered with enthusiastic hymns to the U.S. our question: "What do you like here?" emphasized discrimination in their answers to "What do you dislike here?" Only a few felt that they themselves discriminated against; most of them discuss discrimination the observe towards others:

"It, (U.S.) is the best place in the world," writes an Austrian girl of twelve now living in California. "I never think of belonging to another

country. It is modern. It offers a chance for me. I have a swell time here. Austria was very small. America is great and powerful, something to feel part of, to be proud of. I like schools, government, people. I like churches. I dislike racial difference, the way children in our school stand off the Mexicans.” A Gentile girl of seventeen: "I like everything except the still standing discrimination against Jews and Negroes" and a Jewish boy of 15, who especially likes "the fact that it is not a shame to work manually here" dislikes "discrimination against Negroes, Italians, Irish a[nd] s[o] o[n].” 
"I just heard Marian Anderson sing. That reminds me of the protest in Washington when she, a negress, was to sing there. A spot of the honour of the country. Without such things or perhaps with a little education for such matters - this country and her people could be so excellent and so superior. Too bad, nothing can be nearly perfect.” The then seventeen-year-old German boy, who wrote that the answer is now serving in the Army of the country whose spot he is so sensitive about.

All the 43 British children questioned in our study like America very much but only one fifteen-year-old boy would like to live here, "if my folks weren't still in England." He adds: "People live at such speed. Much less reserved - the people, i.e. control over their emotions much freer, which I like. I don't like some of the narrow-mindedness about foreign countries. In general I like the outspokenness and broadmindedness."

I like schools, stores, theatres. I honestly can't think of anything I dislike. I feel it's a great experience but often wonder how I'll feel when people ask me what I did in the war. Many English children as this eighteen-year-old girl, express in this or another way their embarrassment to be safe here while their country is bombed and in danger, and

while their nation is waging a terrible war. "I live in a city now, therefor more people around. No class distinction - except from coloured people in some places - but colour makes no difference with me.

I like it here. The young have much more freedom and attention. I like everything but air conditioning and the emphasis put on money" answers an eighteen-year-old girl from England and a thirteen-year-old boy states: "The only thing I dislike is the extreme climate. I like the schooling system, but I do not like the long winter. I expected to find The U.S.A: more backward than England, but I find that there are a good deal more luxuries. I get less hope now. (I miss) the mild climate of Britain. I hope that I have not rubbed in the fact that I dislike the climate over here too much."

The seventeen-year- old French boy: "I respect everything that is essential American and am grateful for the shelter it has afforded to me”, expresses well the high regard for America of those children also who intend to go back to their home countries. A twenty-year-old Italian girl, who also feels "a great oath of gratitude toward destiny for a life in the safest and most desirable country in today's world," takes back this impression to her beloved Italy: "What most affected me is the change in standard of living and the different concept of the role a woman here and her opportunities for work." 
"I feel happy here because, obviously, it is the best place to live in right now. Also because I have opportunities here that I would have no place else. The United States must be described - it cannot be compared to other countries ... Pardon the epigram." This "epigram" of an eighteen-year- old girl summarizes the answers of all the children to our question as to their feelings toward a country, where they were not born but where they have found security and belonging, a country to which they have consciously adjusted their emotions and their love. 